\title{
IDEOLOGI DALAM NOVEL NEGERI 5 MENARA KARYA A. FUADI: TINJAUAN IDEOLOGI ALTHUSSER
}

\section{Ideology in The State Of Novel Negeri 5 Menara A. Fuadi: Review Of Althusser Ideology}

\author{
Naila Nilofar \\ Balai Bahasa Jawa Timur \\ Jalan Siwalanpanji, Buduran, Sidoarjo \\ Ponsel +6281231635337 \\ Pos-el: tajunaya@gmail.com \\ tanggal naskah masuk 14 Oktober 2018 \\ tanggal akhir penyuntingan 28 November 2018
}

Abstract

This paper is aimed to analyze novel "Negeri 5 Menara" of A. Fuadi by using Ideology of Althusser approach. Methode that is used in this research is qualitative descriptive. The result of the research is shown that there are capitalisme ideology and religion ideology in novel "Negeri 5 Menara". Capitalism ideology is shown in surround is that people who study in formal institution for they want to get job after they pass study. Other ideology that is shown in novel "Negeri 5 Menara" is religion ideology. Boarding school as a formal institution teaches its students to get knowledge for one reason. It is for Allah only.

Keywords: Novel, Ideology of Althusser, ideology of capitalism, and ideology of religion.

\section{Abstrak}

Tulisan ini bertujuan untuk menganalisis novel "Negeri 5 Menara" karya A. Fuadi dengan menggunakan pendekatan Ideologi Althusser. Metode yang digunakan dalam penelitian ini adalah desktiptif kualitatif. Hasil penelitian menunjukkan bahwa ideologi yang terdapat dalam novel "Negeri 5 Menara" adalah ideologi kapitalis dan ideologi agama. Ideologi kapitalis terlihat dalam masyarakat bahwa orang yang belajar dalam lembaga formal karena ingin mendapatkan pekerjaan setelah lulus sekolah. Ideologi lain yang terlihat dalam novel "Negeri 5 Menara" adalah ideologi agama, yaitu pesantren sebagai lembaga formal mengajarkan kepada para santrinya untuk menuntut ilmu hanya karena Allah semata.

Kata-kata kunci: Novel, ideologi Althusser, ideologi kapitalis, dan ideologi agama.

\section{PENDAHULUAN}

Negeri 5 Menara merupakan buku pertama dari trilogi karya A. Fuadi yang diterbitkan pertama kali pada bulan Juli tahun 2009. Novel ini termasuk jenis karya populer, hal ini terlihat dari banyaknya penjualan novel tersebut. Novel ini masuk dalam daftar rekor penjualan buku terbanyak
Gramedia yaitu dalam jangka waktu kurang dua tahun telah dicetak selama sepuluh kali dengan oplah lebih dari 170.000 eksemplar.

Novel ini bisa dimasukkan ke dalam kategori budaya populer karena novel ini mengandung teks-teks budaya. Melalui novel, seorang pengarang bisa menyampaikan pesan 
tertentu. Demikian juga dengan novel Negeri 5 Menara karya A. Fuadi ini, ada ideologi tertentu yang ingin disampaikan melaui novel ini. Menurut William (Strinati, 2010:2425), populer dipandang dari sudut pandang orang dan bukannya dari mereka yang mencari persetujuan atau kekuasaan atas mereka. Sekalipun demikian, pengertian awal tidaklah mati. Budaya populer bukan diidentifikasi oleh rakyat tapi oleh orang lain, dan masih menyandang dua makna kuno: jenis karya inferior (bdk. Sastra populer, pers populer yang dibedakan dengan pers berkualitas); dan karya yang secara sengaja dibuat agar disukai orang (jurnalisme populer dibedakan dengan jurnalisme demokratik, atau hiburan populer); maupun pengertian modern yang disukai banyak orang, yang tentunya pada banyak kasus bertumpang tindih dengan pengertian lama. Pengertian mutakhir budaya populer sebagai kebudayaan yang sebenarnya dibuat oleh orang-orang untuk kepentingan mereka sendiri yang sama sekali berbeda dengan semua pengertian di atas. Pengertian ini seringkali digantikan pada masa lalu sebagai budaya rakyat, tapi pengertian ini juga merupakan salah satu penekanan modern yang penting.

Makalah ini bertujuan untuk menganalisis novel Negeri 5 Menara karya A. Fuadi dengan pendekatan ideologi Althusser. Penelitian dengan objek material yang sama dengan pendekatan ideologi sudah pernah dilakukan sebelumnya tetapi ada perbedaan di antara kedua penelitian tersebut. Penelitian yang sudah pernah dilakukan menggunakan pendekatan ideologi Fairclough. Peneliti menganalisis ideologi pengarangnya, tetapi penelitian dalam makalah ini menggunakan pendekatan ideologi Althusser. Peneliti menganalisis ideologi yang ada dalam teks novel Negeri 5 Menara bukan ideologi pengarangnya.

Adapun tinjauan dari penelitian terhadap novel Negeri 5 Menara yang sudah pernah dilakukan yakni Representasi Pendidikan Pesantren dalam Novel "Negeri 5 Menara" (Studi Analisis Wacana Norman Fairclough) (Fujiasih), penelitian ini bertujuan untuk mengetahui nilai ideologi penulis, mengetahui wacana pada makna isi pesan yang terkandung dalam novel dan untuk mengetahui representasi pendidikan pesantren yang dibentuk dalam novel "Negeri 5 Menara" ini. Hasil penelitian menunjukkan bagaimana pendidikan pesantren direpresentasikan dan ideologi A. Fuadi sebagai penulis novel "Negeri 5 Menara". Pesantren dalam novel ini direpresentasikan sebagai lembaga pendidikan yang bermutu, memiliki pola pendidikan yang berbeda dengan lembaga pendidikan lain dan mampu menghasilkan alumni yang berkualitas. Adapun ideologi seorang A. Fuadi adalah bagaimana ia mencoba menjelaskan tentang pendidikan pesantren yang selama ini tidak banyak terekspos media dan tidak diketahui apa yang terjadi di balik tembok pesantren.

Penelitian yang hampir sama dilakukan oleh Puspita (2014). Penelitian tersebut menggunakan novel "Negeri 5 Menara" sebagai objek penelitian dan pendekatan Ideologi Althusser dan Hegemoni Dominasi dan Gramsci. Meskipun penelitian ini hanya menggunakan pendekatan Ideologi Althusser, tetapi analisisnya lebih detail dari pada penelitian sebelumnya. 


\section{LANDASAN TEORI}

\section{Teori Ideologi Althusser}

Menurut Althusser, ideologi memiliki dua pengertian, di satu sisi, dia adalah kondisi nyata kehidupan manusia, yang meliputi pandangan dunia yang menjadi landasan orang untuk hidup dan menyelami dunia ini. Di sisi lain, ideologi dipahami sebagai seperangkat makna rumit yang menjelaskan dunia (suatu diskursus ideologi) dengan cara melakukan misrecognize (salah mengenali) misrepresent (salah merepresentasikan) kekuasaan dan relasi kelas (Barker, 2009:60). Bagi Althusser, ideologi ada dalam suatu apparatus dan praktik yang menyertainya; akibatnya, dia terus menjadikan seperangkat institusi, terutama keluarga, sistem pendidikan, gereja, dan media massa, sebagai 'aparatus negara ideologis' (ideological state apparatuses/ISAs). Althusser juga mengatakan bahwa ideologi merupakan sarana yang jauh lebih efektif bagi peneguh kekuasaan kelas ketimbang kekuatan fisik (Barker, 2009:61). Lebih jauh Althusser mengatakan bahwa pendidikan bukan hanya mewariskan ideologi kelas berkuasa yang membenarkan dan melegitimasi kapitalisme, tetapi juga mereproduksi sikap dan perilaku yang dijalankan oleh kebanyakan kelompok kelas dalam pembagian kerja. Ideologi mengajarkan pekerja untuk menerima dan tunduk kepada eksploitasi yang mereka alami sambil mengajarkan para manajer dan administrator mempraktikkan keterampilan menguasai atas nama kelas dominan (Barker, 2009:61).

Berdasarkan uraian tersebut, yang dimaksud dengan ideologi ada dua pengertian, yaitu 1) pandangan seseorang yang digunakan sebagai pedoman untuk memahami dunia dan 2) seperangkat makna rumit yang menjelaskan dunia (diskursus ideologi).

Ada empat aspek yang menjadi inti pandangan Althusser tentang ideologi, yaitu:

1) Ideologi memiliki fungsi umum untuk membentuk subjek.

2) Ideologi sebagai pengalaman yang dijalani tidaklah palsu.

3) Ideologi sebagai pemahaman yang keliru tentang kondisi nyata eksistensi adalah palsu.

4) Ideologi terlibat dalam reproduksi formasi-formasi sosial dan relasi mereka terhadap kekuasaan.

(Barker, 2009:59).

Bagi Althusser, titik masuk kita ke dalam tatanan simbolis (bahasa) dan terbentuknya diri kita sebagai subjek (person) adalah hasil kerja ideologi. Althusser berpendapat bahwa ideologi memuji dan mempertanyakan individu sebagai subjek konkret. Ideologi berfungsi untuk membentuk individu konkret sebagai subjek (Barker, 2009:59). Althusser mengemukakan bahwa ideologi menginterpelasi individu sebagai subjek (2002:242). Adapun subjek, memiliki dua makna umum, yaitu 1) subjek dimengerti sebagai pengertian subjek dalam kalimat dan 2) subjek dimengerti seperti pengertian bagaimana kita berbicara tentang seseorang sebagai tunduk pada hukum tanah, atau (dalam beberapa kasus) seorang yang tunduk pada sang Ratu.

Althusser berusaha menjelaskan pengertian interpelasi dengan cara menggunakan sebuah kisah sebagai ilustrasi. Althusser menyuruh kita membayangkan kita sedang berjalan di ujung jalan, tiba-tiba ada seseorang 
yang memanggil, 'Hei, Anda yang di sana!'. Suara itu bukan suara orang yang kita kenal dan nama kita tidak disebut dalam panggilan tersebut. Tidak ada alasan bahwa suara itu memanggil kita, namun kita berpaling seperti kita berpaling ketika kita adalah orang yang dimaksud. Setiap orang memiliki cara yang berbeda untuk merespon panggilan tadi (2002:241-242).

Kisah tersebut merupakan ilustrasi proses interpelasi dalam cara kerja ideologi.

Lebih jauh Althusser menjelaskan bahwa interpelasi menghasilkan alamat dengan dua posisi tidak simetris dan satu relasi yang menghubungkannya (2002:245-246), yaitu:

1) subjek yang diinterpelasi. Ini adalah posisi si alamat, posisi yang ditawarkan pada individu yang menoleh pada panggilana di jalan itu, peran yang di dalamnya dia diajak untuk mengenal dirinya sendiri. Ini diasosiasikan sebagai fungsi konotatif.

2) Subjek yang menginterpelasi. Ini adalah posisi si pengalamat, posisi hukum. Ini diasosiasikan sebagai fungsi ekspresif.

3) Relasi phatic yang menghubungkan subjek dengan subjek itu. Relasi ini adalah relasi komunitas interpelasi. Relasi ini mengikat bersama semua subjek yang diinterpelasi melalui relasi umum mereka dengan Subjek atau hukum yang menginterpelasi.

Althusser mengungkapkan juga, bahwa formasi sosial sebagai suatu struktur kompleks dari berbagai hal berbagai level atau praktik) yang 'dominasinya terstruktur'.

\section{METODE PENELITIAN}

Metode yang digunakan dalam penelitian ini adalah metode kualitatif deskriptif analitik. Metode kualitatif adalah metode untuk menafsirkan kata-kata dengan cara mendeskripsikan (Ratna, 2006:46-47). Sumber data penelitian kualitatif dalam ilmu sastra adalah karya, naskah, dan data penelitiannya. Data formalnya adalah kata-kata, kalimat, dan wacana. Dengan demikian, sumber data dalam penelitian ini adalah novel "Negeri 5 Menara" karya A. Fuadi. Adapun data formalnya adalah kata-kata, kalimat, dan wacana yang mengandung ideologi.

Adapun metode deskriptif analitik adalah metode yang dilakukan dengan cara mendeskripsikan faktafakta kemudian diikuti dengan analisis (Ratna, 2006:53). Pada penelitian ini, penggunaan metode tersebut didukung dengan teori ideologi althusser. Adapun langkah-langkah untuk menganalisis data dalam penelitian ini adalah sebagai berikut:

1) menentukan data dalam penelitian ini, yaitu kata-kata, kalimat, dan wacana dalam novel "Negeri 5 Menara" karya A. Fuadi yang bisa diidentifikasi sebagai ideologi.

2) Mengidentifikasi kata-kata, kalimat, dan wacana yang menunjukkan adanya reproduksi tenaga kerja.

3) Mengidentifikasi kata-kata, kalimat, dan wacana yang bisa dianggap sebagai interpelasi. 
PEMBAHASAN

Novel Negeri 5 Menara menceritakan tentang kehidupan pesantren di Jawa Timur. Pesantren merupakan salah satu lembaga pendidikan di negara Indonesia. Struktur masyarakat di pesantren terdiri atas pemimpin dan siswa. Kiai menduduki posisi pemimpin di pesantren, adapu santri, siswa yang mencari ilmu di pesantren menduduki posisi siswa. Berdasarkan teori Althusser, kyai bisa disebut superstruktur dan santri bisa disebut basis struktur. Sebagaimana yang dikatakan Althusser, mengenai hubungan basis-superstruktur, bahwa Marx memahami struktur setiap masyarakat terdiri atas "lapisanlapisan" atau "contoh-contoh" yang dipertegas oleh suatu determinasi khusus: infrastruktur, atau basis ekonomi ("kesatuan" antara kekuatankekuatan produktif dan relasi-relasi produksi) dan superstruktur, yang dengan sendirinya berisi dua "lapis" atau "contoh": legal-politis (hukum dan negara) dan ideology (ideologi, agama, etika, hukum, politik yang berbeda-beda, dan sebagainya) (Strinati, 2010:232).

\section{Ideologi}

Dalam novel Negeri 5 Menara karya A. Fuadi digambarkan bahwa ideologi yang berkembang di masyarakat adalah seseorang belajar di suatu lembaga pendidikan formal digunakan sebagai sarana untuk mendapatkan pekerjaan. Bukti yang digunakan seseorang untuk menunjukkan bahwa dia sudah mendapat pendidikan formal adalah bukti yang berupa ijazah. Ijazah tersebut bisa digunakan seseorang untuk mendapatkan pekerjaan. Dengan pekerjaan tersebut, seseorang akan mendapatkan uang yang bisa memenuhi kebutuhan materialnya. Dengan demikian dapat dikatakan bahwa ideologi yang berkembang dalam masyarakat adalah ideologi kapitalis (ada pemilik modal dan pekerja).

Sedangkan belajar di pesantren, yang juga merupakan lembaga pendidikan formal, seorang santri tidak akan mendapat ijazah. Hal ini berhubungan dengan ideologi yang ditanamkan kyai, penguasa pesantren kepada para santrinya. Kyai atau penguasa pesantren menanamkan ideologi kepada para santrinya untuk menuntut ilmu karena Tuhan semata. bukan untuk gagah-gagahan atau hanya agar bisa berbahasa asing.

Kiai Rais kembali
melanjutkan pidato:
"Menuntut ilmu di PM
bukan buat gagah-gagahan
dan bukan biar bisa bahasa
asing. Tapi menuntut ilmu
karena Tuhan semata.
Karena itulah kalian tidak
akan kami beri ijasah, tidak
akan kami beri ikan, tapi
akan mendapat ilmu dan
kail (Fuadi, 2010:50).

Dari kutipan di atas, nampak bahwa siswa yang lulus dari pesantren tersebut tidak akan diberi ijazah. Kyai mengilustrasikan pesantren sebagai tempat memancing yang dapat ditafsirkan sebagai tempat mencari ilmu. Kyai tidak akan memberi ikan tetapi hanya akan memberi ilmu dan kail. Siswa hanya akan diberi ilmu dan cara bagaimana untuk bekerja. Kyai juga menjelaskan bahwa pesantren tidak akan memberikan ijazah bagi para siswanya yang telah lulus. Hal di atas menunjukkan adanya wacana etika mencari ilmu, yaitu bahwa 
lembaga pendidikan bukan hanya digunakan untuk mencari ijazah, tetapi untuk mendapatkan ilmu dan pengetahuan.

Ideologi kapitalisme yang berkembang di masyarakat, secara tidak disadari telah menghegemoni Alif, salah satu santri di pesantren. Dia merasa kawatir bahwa dengan belajar di pesantren, dia tidak akan berhasil meraih cita-citanya sebagai seorang insinyur. Dia menganggap bahwa setelah lulus dari pesantren hanya akan menjadi seorang ustadz atau guru ngaji. Alif terhegemoni bahwa dengan menjadi ustadz atau guru ngaji tidak akan bisa menghasilkan materi yang berlimpah.

\section{Reproduksi Tenaga Kerja}

Reproduksi tenaga kerja di pesantren dilakukan oleh kyai dengan beberapa cara, antara lain sebagai berikut.

a. memberi semangat belajar para santri dengan cara memberikan kata-kata nasehat secara berulang-ulang 'man jadda wa jada'. Nasihat yang diberikan oleh kyai tersebut berbahasa Arab yang artinya barang siapa yang rajin berusaha maka akan menjadi sukses. Kata-kata tersebut sangat berperan dalam kehidupan para santri sehingga mereka tetap semangat dalam dan tidak mudah putus asa dalam mengerjakan tugastugas yang diberikan oleh pengajar-pengajar mereka.

Selain 'man jadda wa jada', kyai juga memberikan kata-kata semangat lain 'man shabara zafira'. Kata-kata tersebut juga berasal dari bahasa Arab yang artinya barang siapa yang bersabar akan meraih kemenangan. Kata-kata tersebut bisa membangkitkan semangat para santri yang merasa lelah ketika mengerjakan tugas yang berat dari para pengajar mereka.

b. Memberikan peraturanperaturan yang wajib ditaati para santri. Peraturanperaturan tersebut antara lain tidak berupa peraturan secara tertulis, tetapi hanya diucapkan di depan para santri. Aturanaturan tersebut dibacakan oleh dewan yang telah ditunjuk oleh pengurus pesantren. Peraturanperaturan tersebut antara lain sholat lima waktu tepat pada waktunya, belajar sesuai dengan jam yang ditentukan, wajib berbahasa Arab pada hari-hari yang telah ditentukan, wajib berbahasa Inggris pada hari-hari yang telah ditentukan. Aturan-aturan yang berlaku di pesantren diawasi oleh dewan keamanan pesantren yang sangat tegas. Dengan kata lain kyai menunjuk dewan keamanan untuk mengamankan reproduksi tenaga kerjanya.

Secara tidak langsung, aturan-aturan yang diberlakukan bagi para santri, seperti wajib berbahasa Arab dan Inggris mengharuskan para santri untuk memiliki Kamus Bahasa Arab dan Bahasa Inggris. Dengan demikian, para santri akan membeli kamus yang disediakan di koperasi pesantren. Hal itulah, yang disebut Althusser sebagai determinisme ekonomi. Dalam dunia nyata, determinisme 
ekonomi tidak pernah hadir dalam bentuk murninya sehingga keberadaannya maupun dampaknya senantiasa sukar untuk diputuskan dan dijabarkan dari berbagai pengaruh lainnya. Demikianlah cara Althusser menginterpretasi gagasan Marx bahwa superstruktur tidak hanya ditentukan oleh basisnya, tapi juga oleh berbagai macam faktor sekunder, kebetulan, dan kontingen sifatnya dari yang bersifat lokal dan eksternal (Strinati, 2010:230-231).

c. Usaha lain yang digunakan oleh penguasa pesantren untuk reproduksi tenaga kerja adalah melakukan pergantian pengurus siswa di pesantren, dari siswa senior ke adik angkatannya. Siswa senior akan segera lulus dan kembali ke masyarakat untuk mengabdikan hidupnya. Tugas lembaga pendidikan adalah mereproduksi berbagai faktorfaktor produksi, dalam hal ini siswa dianggap sebagai faktor produksi.

Kekuasaan kami sangat riil dan meliputi semua bidang, mulai dari urusan penyediaan makan buat warga PM, masalah wesel sampai keamanan. Pendeknya, mandate kami adalah menjalankan roda kegiatan PM dari hulu ke hilir. Tampuk kekuasaan ini kami dapatkan ketika naik kelas 5, setelah pergantian organisasi pengurus siswa. Kini jabatan ini akan segera kami serahkan ke adik kelas kami dua bulan lagi. Sedangkan kami siswa kelas 6 disuruh fokus semata untuk belajar mempersiapkan ujian akhir. Pelajaran dari kelas $1-$ 6 diujikan dalam ujian marathon 15 hari (Fuadi, 2010:290).

\section{Penciptaan Subjek-Subjek/ Interpelasi}

Ideologi yang ditanamkan kepada para siswa di pesantren salah satu caranya adalah dengan melakukan penciptaan subjek-subjek. Pemimpin pesantren memanggil para siswa dengan sebutan 'para pencari ilmu'. Orang yang dipanggil namanya akan merasa menjadi subjek. Demikian juga dengan para siswa yang dipanggil dengan sebutan 'para pencari ilmu' akan merasa menjadi subjek. Kemudian subjek tersebut tersubjektifikasi, padahal subjek tersebut hanya objek semata.
"Marhaban.
Selamat datang anak-anakku para pencari ilmu. Welcome. Selamat datang. Bien venue. Saya selaku rais ma'had pimpinan pondok dan para guru di sini dengan sangat bahagia menyambut kedatangan anak-anak baru kami untuk ikut menuntut ilmu di sini. Terima kasih atas keperca- yaannya, semoga kalian betah. Mulai sekarang kalian semua adalah bagian dari keluarga besar PM," Kiai rais membuka sambutannya. Suaranya dalam dan menenangkan (Fuadi, 2010:49).

Ketika pertama kali menjadi siswa di pesantren tersebut, para siswa dikumpulkan di sebuah aula dan pemimpin pesantren memberikan 
sambutan kepada mereka untuk diterima menjadi keluarga besar pesantren tersebut. Para siswa dipanggil dengan sebutan 'para pencari ilmu'. Setelah para siswa merasa menjadi subjek pencari ilmu, mereka diberi peraturan-peraturan yang harus mereka jalani dan taati ketika menjadi siswa di pesantren tersebut. Jika mereka melanggar peraturan akan diberi hukuman. Dengan demikian, para siswa yang sudah merasa menjadi subjek ternyata hanya merupakan objek semata. Hukum yang berlaku bagi para siswa di pesantren tersebut dipertegas pemimpin pesantren sebagai berikut.

"Selain itu, ingat juga bahwa aturan di sini punya konsekuensi hukum yang berlaku tanpa pandang bulu. Kalau tidak bisa mengikuti aturan, mungkin kalian tidak cocok di sini. Malam ini akan dibacakan qanun, aturan komando. Simak baik-baik, tidak ada yang tertulis, karena itu harus kalian tulis dalam ingatan. Setelah mendengar qanun, setiap orang tidak punya alasan tidak tahu bahwa ini aturan." (Fuadi, 2010:51).

Menurut Althusser, subjek adalah ciri pembeda dari semua ideologi, dan seluruh ideologi bekerja atau berfungsi dengan mengambil individu dan menempatkannya, artinya menuntut mereka, sebagai subjeksubjek di dalam kerangka ideologi. Sebagai contoh, sebuah agama akan menempatkan seluruh individu yang berperan serta dalam berbagai praktik materiil sebagai subjek atau penganut, yang tunduk kepada satu subjek, Tuhan (Strinati, 2010:239). Dalam hal ini, siswa-siswa di pesantren yang dipanggil dengan sebutan 'para pencari ilmu' akan tunduk dan patuh kepada peraturan-peraturan gurunya.

\section{PENUTUP}

Berdasarkan analisis di atas dapat disimpulkan bahwa ideologi yang ada dalam novel Negeri 5 Menara karya A. Fuadi adalah ideologi kapitalisme, yaitu seseorang belajar di suatu lembaga pendidikan formal bertujuan untuk mendapatkan pekerjaan. Di sisi lain, pesantren sebagai lembaga pendidikan formal mengajarkan ideologi agama yaitu mencari ilmu karena Tuhan semata. Untuk melanggengkan posisi kyai sebagai penguasa pesantren, kyai melakukan reproduksi tenaga kerja dengan cara memberi semangat para santri untuk giat belajar dengan katakata bijak, memberikan peraturanperaturan yang wajib ditaati oleh para santri, dan melakukan penggantian pengurus pesantren yang senior digantikan oleh adik angkatannya. Untuk mengontrol ketaatan para santri, kyai menunjuk dewan keamanan. Selain melakukan reproduksi tenaga kerja, kyai juga melakukan subjektivikasi terhadap para santri.

\section{Daftar Pustaka}

Barker, Chris. (2009). Cultural Studies: Teori dan Praktik. Yogyakarta: Kreasi Wacana.

Fuadi, A. (2010). Negeri 5 Menara. Jakarta: PT. Gramedia Pustaka Utama.

http://repository.usu.ac.id/bitstream/12 3456789/21260/7/Cover.pdf.

Puspita, Alvi. (2014). "Novel Negeri 5 Menara Kepopuleran dan Ideologi (Kajian Ideologi 
Althusser dan Hegemoni Dominasi Gramsci)". Jurnal Pustaka Budaya, 1(2), http://ejurnal.unilak.ac.id/ind ex.php/pb

Ratna, Nyoman Kutha. (2006). Teori, Metode, dan Teknik Penelitian Sastra. Yogyakarta: Pustaka Pelajar.
Strinati, Dominic. (2010). Populer Culture. Jogjakarta: Arruz Media.

Thwaites, Tony, Lloyd Davis, dan Warwick Mules. (2002). Introducing Cultural and Media Studies: Sebuah Pendekatan Semiotik. Yogyakarta: Jalasutra. 